\title{
Terminológiaoktatás és -kutatás a fordítóképzésben ${ }^{1}$
}

\author{
Fóris Ágota \\ E-mail:foris.agota@kre.hu
}

\begin{abstract}
Kivonat: A magyar felsőoktatásban mesterszintü fordító és tolmács mesterszak, továbbá szakirányú fordítói továbbképzések széles választéka müködik; fordítástudományi doktori program csak az ELTE-n van. A terminológiát különbözö óraszámban és tartalommal tanítják ezekben a képzésekben, a terminológia oktatásával és kutatásával foglalkozó kollégák pedig számos tanulmányt jelentettek meg a terminológia fordításoktatási vonatkozásairól. A tanulmány célja a terminológia oktatásának és kutatásának összefoglaló áttekintése a magyarországi fordítástudományi doktori képzésben és a fordítóképzésben.
\end{abstract}

Kulcsszavak: terminológiaoktatás, terminológiakutatás, fordítóképzés, fordítástudományi doktori képzés, terminológiamenedzsment

\section{Bevezetés}

A tanulmány célja a terminológia oktatásának és kutatásának összefoglaló bemutatása a fordítástudományi doktori képzésben és a fordítóképzésben. A magyar felsőoktatásban a magyar nyelvü szaknyelv- és a terminológiaoktatás hosszú ideig a szakmai képzéshez, az idegen nyelvü szaknyelv- és a terminológiaoktatás pedig a szakfordítóképzéshez kapcsolódott. A bolognai rendszer keretében lehetőség nyílt arra, hogy az alapképzésekre építve új típusú alkalmazott nyelvészeti szakok indulhassanak, köztük a fordító és tolmács mesterszak, továbbá szakirányú fordítói továbbképzések széles választéka. A terminológia különböző óraszámban és tartalommal jelent meg ezekben a képzésekben, a terminológia oktatásával (és kutatásával) foglalkozó kollégák pedig számos tanulmányt jelentettek meg a terminológia fordításoktatási vonatkozásairól.

Hivatkozás: Fóris Á. 2021. Terminológiaoktatás és -kutatás a fordítóképzésben. Fordítástudomány 23. évf. 2. szám. 5-23. DOI: https://doi.org/10.35924/fordtud.23.2.1

\footnotetext{
${ }^{1}$ A tanulmány a Forditás és terminológia. Elmélet és gyakorlat címü könyv (Fóris 2020) A forditástudomány és terminológiatudomány és A terminológia oktatása a fordítóképzésben címü fejezeteinek átdolgozott változata.
} 
A terminológia önálló diszciplínaként a bölcsészettudományi karokon is megjelent, elsősorban a nyelvészeti képzésekben (magyar nyelvészeti, alkalmazott nyelvészeti képzések és specializációk), majd önálló mesterszakként is bekerült a magyar felsőoktatásba (a terminológusképzésről lásd pl. Fóris 2012, 2013). A terminológus olyan szakember, aki rendelkezik azokkal a terminológiai, módszertani, anyanyelvi, idegen nyelvi és szaktárgyi ismeretekkel, valamint kompetenciákkal, amelyekkel képes a terminológia elveinek megfelelően terminológiai dokumentációs munkák végzésére, a terminológia területén használt eszközök és módszerek alkalmazására (B. Papp et al. 2014). A terminológusok feladatköre sokrétü: feladatuk a tudásmenedzsment, azaz a céggel, a termékkel és a szakterülettel kapcsolatos információk gyüjtése, rendszerezése, karbantartása és hozzáférhetővé tétele egy vagy több nyelven. A fordítóipar az a terület, ahol a legnagyobb szükség van terminológusokra, és a végzett terminológusok nagyobbrészt ezen a területen helyezkedtek el különféle munkakörökben (pl. terminológus, nyelvi vezetö, nyelvi menedzser, projektmenedzser).

Tapasztalataim szerint a bölcsészettudományi karokon folyó mesterszakos terminológusképzésben és a fordítóképzésben részt vevő hallgatók előképzettsége különböző: a terminológusképzésbe nagyobbrészt magyar alapképzésről, míg a fordítóképzésbe nagyobbrészt idegen nyelvi alapszakokról érkeznek a hallgatók, ennek megfelelően a nyelvészeti előképzettségük is különböző. A fordítói szakirányú specializációkban és továbbképzéseken pedig a legkülönfélébb képzettségü hallgatók vesznek részt (közgazdasági, jogi, müszaki, agrár stb. tanulmányok közben vagy azt követően).

A fordítóképzések többségében a terminológia egy vagy két kurzus keretében oktatott tárgy, célja elsősorban az, hogy a fordítók megszerezzék azokat az alapvető ismereteket, amelyek segítik őket abban, hogy a fordítási folyamat során sikerrel azonosítsák a terminusokat a forrásnyelvben és minél sikeresebben találják meg ezek célnyelvi ekvivalenseit, valamint hogy képesek legyenek a saját szakterületük terminológiájának adatbázisokban való sikeres kezelésére, vagyis a terminológiamenedzsmentre.

A továbbiakban két területet tekintek át a fordításoktatással kapcsolatosan: a terminológia helyét és szerepét a fordítástudományi doktori képzésben és a fordítóképzésben.

\section{Terminológia a fordítástudományi doktori képzésben}

Mind a fordítástudomány, mind a terminológiatudomány viszonylag fiatal tudományterület, pedig évszázadok óta léteznek alkalmazott nyelvészeti tevékenységként. Hasonlítanak abban, hogy mindegyik interdiszciplináris tudományterület, de különböznek abban, hogy a fordítástudomány szövegekkel foglalkozik, a terminológiatudomány tárgya pedig a terminusok, a fogalmak, a terminológiai és a fogalmi rendszerek vizsgálata, leírása és menedzselése; a fordítástudomány szempont- 
jából a terminológia inkább csak egy, a szakmai kommunikációban használt eszközként jelenik meg. A fordítás elsősorban a kommunikációs folyamatra összpontosít, ebben a folyamatban a terminológia csak egy része egy szakszöveg által közvetített üzenetnek. Montero Martínez és Faber (2009) szerint ennek a megközelítésnek az az eredménye, hogy a fordításnak használnia kell a terminológiát a speciális tudásegységek nyelvek közötti átadásához, de a terminológiának nincs szüksége arra, hogy a fordításhoz forduljon - vagyis a két terület viszonya aszimmetrikus.

Klaudy Kinga több müvében is foglalkozott a fordítástudomány és más tudományterületek közötti kapcsolatokkal, köztük a fordítástudomány és a terminológiatudomány viszonyával (Klaudy 2015, Klaudy 2017), és megállapította, hogy: „A fordítástudomány szoros kapcsolata a terminológia tudományával kézenfekvőnek tünik, de mégsem az" (Klaudy 2015: 179). A fordítástudomány és a terminológia kapcsolatai az utóbbi időszakban erősödtek meg, elsősorban a fordítói munka megváltozott körülményei miatt:

(...) a technológia fejlödése következtében gyökeresen megváltoztak a fordítói munka körülményei, a szótárt forgató magányos fordító helyett terminológiai adatbázisokat használó csapatmunkás a kutatás alanya, akinek egy kattintással feltárul a szavak mögötti világ, de ugyanezek az eszközök a megrendelök számára is elérhetők, tehát megszünik a fordító egyeduralma az interlingvális és interkulturális kommunikációs eszközök felett. (Klaudy 2015: 179)

A fordítástudomány - mint tudományterület - célja a fordítók tevékenységének és maguknak a fordított szövegeknek a kutatása. Klaudy Tizenöt tézis a forditástudományról címủ írásában így fogalmazza meg a fordítástudomány célját: a fordítástudomány célja „a fordítói tapasztalat rendszerbe foglalása” (1. tézis); ,,az általános fordítástudomány célja, hogy minél többet tudjunk meg a fordítás folyamatáról, eredményéről, funkciójáról” (9. tézis); ,a magyar fordítástudomány célja, hogy minél többet tudjunk meg a magyar fordítók és tolmácsok kognitív átváltási folyamatairól, a fordítás eredményeképp keletkezett magyar szövegekröl és a fordítás funkciójáról a magyar társadalomban” (10. tézis); ,a fordítástudomány »segédtudományait« a fenti három kutatási tárgy jelöli ki: a fordítás folyamatának kutatásában a pszicholingvisztikával és a kognitív nyelvészettel, a fordítás eredményének kutatásában a szövegnyelvészettel, a stilisztikával és az irodalomtudománnyal, a fordítás funkciójának kutatásában pedig megint csak az irodalomtudománnyal, valamint a szociolingvisztikával és a pragmatikával érintkezik" (11. tézis) (Klaudy 2008: 40-51).

Amikor Klaudy a „fordítás folyamatáról” ír, akkor a fordítási folyamaton az egyéni fordítói tevékenységet érti, és ennek tudományos vizsgálatát tartja szükségesnek. Ahogyan azonban Klaudy is írja, a fordítás körülményei megváltoztak: a magányos fordító helyett a fordító csapatmunkás, lett a fordítási projektfolyamat része, egyik szereplője. Ezért szinte evidens, hogy megjelent a fordítástudomány 
vizsgálati témái között a fordítóirodáknál folyó „fordítási folyamat”, amelynek csak egyetlen fázisát képezi a korábban „fordítás”-nak nevezett egység. Azért, hogy egyértelmüen megkülönböztessem a hagyományos értelemben vett fordítási folyamattól, ezt a munkafolyamatot fordítási projektfolyamat-nak nevezem.

Erröl a Terminológia a fordítási projektfolyamatban címü fejezetben írok részletesebben (Fóris 2020), valamint Faludi Andrea PhD-értekezésében elemzi lépésről lépésre ezt a komplex folyamatot (Faludi 2020). Ebben a fordítási projektfolyamatban jelenik meg a terminológiai előkészítés és a lektorálás fázisa, valamint a fordítók munkáját segítő fordítási környezetek, közöttük a terminológiakezelő szoftverek; ezek azok, amelyek a korábbiaknál szorosabb közelségbe hozták a terminológiát és a fordítást egymással. És mivel maga a fordítási munkafolyamat (mint gyakorlat) bővült és vált sokrészessé és sokszereplőssé, ezért a fordítástudomány vizsgálati területét is ki lehet és ki is kell terjeszteni az új fázisok és szereplők tevékenységének a vizsgálatára is. Ennek jó példája A modern forditó és tolmács címü könyv (Horváth 2015b), melynek tanulmányai - a szerzők kutatásai alapján - már a modern fordítói projektfolyamat egyes elemeit tárgyalják olyan szempontból, hogy milyen sok mindenből áll össze a fordítási projektfolyamat, milyen új szakmák jelentek meg a nyelvi közvetítői piacon, és hogy milyen ismereteket szükséges a fordítóképzésben oktatni.

Eszenyi Réka (2015) tanulmányában részletesen leírja, milyen elvárások vonatkoznak a fordítóra (mint egyénre). Az Európai Unió Fordítási Főigazgatóságának EMT (European Masters in Translation) szakértői csoportja által 2009-ben kidolgozott modell elsősorban a felsőoktatásban müködő fordítóképző intézmények számára nyújt útmutatást, és hat fö készségterületre bontja le a fordítói kompetenciákat. Ezek: fordítói szolgáltatások nyújtása, nyelvi kompetencia, interkulturális kompetencia, információkereső kompetencia, müszaki-technikai kompetencia, tematikus (tkp. szakterületi) kompetencia. Lásd még az Európai Uniós EMT csoport új ajánlásait (EMT Competence Framework - 2017). Új szakmák, szakmai területek például a fordításszolgáltatás (Szondy 2015), lektorálás (Robin 2015), terminológiai munkák (Tamás 2015), projektmenedzsment (Földes 2015), vendormenedzsment (Wagner 2015), fordítások terminológiai előkészítése és utómunkája (Varga K. 2015), lokalizáció (Snopek 2015), ipari fordításértékelés (Lengyel 2015); továbbá külön fejezet foglalkozik az információs és kommunikációs technológiák szerepével a fordításban és a tolmácsolásban (Ábrányi 2015, Horváth 2015a, Varga Á. 2015) és ezek oktatási vonatkozásaival.

Magyarországon a fordítástudomány és a terminológiatudomány összekapcsolódását segítette az ELTE BTK Fordítástudományi Doktori Programjában ${ }^{1}$ folyó tudományos munka (Klaudy 2013, Klaudy 2014). A doktori program 2003-ban indult Klaudy Kinga vezetésével, aki innovatív és interdiszciplináris szemlélettel viszonyult a fordítástudományi kutatásokhoz, amelyek során elsősorban a leíró és az alkalmazott nyelvészet empirikus kutatási módszereit alkalmazva végezték és végzik a doktoranduszok a kutatásokat. Magában a képzésben is jelentős szerepet kaptak a kutatásmódszertani ismeretek. Ebben a programban volt lehetőség olyan 
kutatási témák meghirdetésére, amelyek a fordítás és a terminológia határterületéhez tartoztak. ${ }^{2}$ E disszertációk megszületése többek között azért is volt nagyon hasznos, mert minden egyes, a téma feldolgozását megkezdö kutató alapos könyvtári kutatómunkát végzett, felderítette, elemezte és összegezte a szakirodalmi előzményeket (forrásként referenciaműveket, tudományos írásokat, szakmai kézikönyveket, szabványokat használtak fel). Mindegyikük összegyüjtötte és leírta a legfontosabb alapfogalmakat és ezek definícióit, és rámutattak a szakirodalmakban található hasonló felfogásokra, megközelítésekre és esetleges ellentmondásokra is. Elsősorban a magyar, angol, német, francia, olasz, spanyol és katalán nyelvü terminológiai és fordítástudományi témájú szakirodalom feldolgozása történt meg e munkák során. Az alábbiakban röviden ismertetem azoknak az értekezéseknek a témáját, amelyek kifejezetten a fordítás és a terminológia határterületén születtek.

Fischer Márta (2011) A fordító mint terminológus, különös tekintettel az európai uniós kontextusra címü értekezésében azt vizsgálja egyrészröl, hogy a fordítási munkafolyamat mely pontjain fordulhat elö, hogy a fordítónak terminológiai munkát kell ellátnia, és ehhez milyen ismeretekre van szüksége, másrészről, hogy a fordítónak milyen terminológiai jellegű munkát kell ellátnia az európai uniós intézményeknél. Az európai uniós környezetben a fordító szerepe annyiban speciálisnak tekinthető, hogy az általuk kiválasztott vagy létrehozott terminusok általában beépülnek az adott szakterület (európai uniós) terminológiájába, és ezzel - a fordítás eredményeként - elfogadott terminussá válnak.

Tamás Dóra (2011) A gazdasági szakszövegek forditásának terminológiai kérdéseiröl az olasz-magyar nyelvpár esetében címü értekezésének témája, hogy milyen szemléletmóddal, módszerekkel és modern, megbízható eszközökkel lehet a gazdasági szakfordítók munkáját segíteni és a gazdasági szakfordítások minőségét javítani. Vizsgálatainak középpontjába a terminológiát helyezte, és annak szerepét vizsgálta nyelvészeti megközelítésböl és a fordítói gyakorlat, elsősorban a fordítói segédeszközök nézőpontjából. Elemezte továbbá a nyomtatott és elektronikus fordítói segédeszközök formai és tartalmi elemeit, valamint a gazdasági terminusok szótári ekvivalenseit nyomtatott és elektronikus szakszótárakban (olasz-magyar nyelvpárban). Ezen túl terminológiai adatbázisok elemzését végezte el, ezek között a trieszti és a bolognai egyetemek terminológiai adatbázisát és tudásbázisát ismertette.

Bereczné Szép Beáta (2014) A szakforditás szerepe a magyar gazdasági jogi szakszókincs kialakulásában címü értekezésében 150 évet átfogó, diakrón szempontú vizsgálatokat végzett a magyar gazdasági jog terminusaira vonatkozóan; ennek során a terminusalkotást és a magyar-német szakfordítás ebben játszott szerepét, a szaknyelvben végbemenő jelentésváltozásokat, a terminusoknak a szaknyelvben való rögzülését, valamint esetleges kiveszését elemezte. A 19. századi magyar nyelvújítás és a kodifikációs törekvések jelentős szerepet játszottak a magyar gazdasági jogi szakszókincs kialakulásában.

Sermann Eszter (2014) A terminológiai szabványositás és a terminológiai harmonizáció fordítási vonatkozásai címú értekezésében a terminológiai szabványo- 
sítás és a terminológiai harmonizáció szakirodalmának és gyakorlatának kritikai áttekintését végzi el. Bemutatja a terminológiai szabványosítás nyelvpolitikai és fordítási vonatkozásait, és a nemzetközi és a nemzeti terminológiai szabványosítás kérdésköréhez kapcsolódva vizsgálja és elemzi a fordításra és a terminológiai munkafolyamatokra vonatkozó ISO szabványokat, valamint ezek hasznosíthatóságát a terminológusképzésben, a fordítóképzésben és terminológiai adatbázisok készítésében. Több esettanulmányt is tartalmaz a disszertáció, többek között spanyolországi terminológiai vonatkozású honlapok és terminológiai adatbázisok vizsgálatát.

Zabóné Varga Irén (2015) Müszaki szövegek forditásának terminológiai problémái német-magyar nyelvpárban jármüipari szövegek alapján címü értekezésében a német-magyar szakfordítással, e nyelvpár müszaki szótárainak jellemzőivel és használhatóságával, a müszaki szaknyelvoktatás nehézségeivel, a német nyelvü müszaki szakszövegek fordításakor felmerülö tipikus nyelvi problémákkal, a jármütechnika területén használatos szövegfajtákkal és a járműipari szövegek terminológiájának vizsgálatával foglalkozik.

Faludi Andrea (2020) A terminológiai munka helye és szerepe a dokumentációkészités és -forditás komplex folyamatában címü értekezésének témája a müszaki dokumentációkészítés és -fordítás folyamatának projektszemléletü, tudományos vizsgálata. A fordítás eredményének minőségét több tényező határozza meg, ezek között az egyik tényező az eredeti szöveg (a forrásszöveg) minősége - ebben pedig kulcsszerepe van a megfelelö terminushasználatnak. A müszaki termékleírásokat szakszövegírók (,technical writer”-ek) készítik, és ezeket a forrásszövegeket fordítják a fordítóirodák egy vagy több más nyelvre (pl. magyar nyelvre) a fordítási projektfolyamat során.

Fontosnak tartom még megemlíteni azokat az értekezéseket is, amelyek a fordítás minőségének kérdéseivel, illetve a fordítás számítógépes hátterével, annak optimalizálásával foglalkoztak, mivel ezekben közvetlenül vagy közvetve megjelennek a terminológia kérdései is. Ezek a következők: Varga Ágnes (2012) A gépi forditás minősége és javitási lehetőségei, Lengyel István (2014) A forditási hiba fogalma funkcionális megközelitésben, Mohácsi-Gorove Anna (2015) A minöség fogalma a forditástudományban és a lektorálás mint minőségbiztositási garancia, Ábrányi Henrietta (2015) A forditási környezetek hatása a fordítás minöségére.

\section{A terminológia oktatása a fordítóképzésben}

A fordítás és a terminológia kapcsolatát többféle nézőpontból szokás tanulmányozni. Amikor a fordítás és a terminológia kapcsolata kerül szóba, akkor - a fordítói (és fordítástudományi) nézőpontból - általában három fontos kérdéskört tárgyalnak a különböző szerzők, amelyek mind a fordítói gyakorlatból erednek: (1) a terminushasználat (a fordítók konkrét terminusokat keresnek); (2) a terminológiai adatbázisok használatának kérdései (hogyan épülnek fel, milyen adatokat tartalmaznak, mire és hogyan használhatók); (3) a terminológiával kapcsolatos ismere- 
tek oktatása, átadása a fordítóképzésben. Az alábbiakban ez utóbbi témakört fejtem ki bővebben.

\subsection{Egyetemi szintű és szakirányú továbbképzések}

Magyarországon a fordító- és tolmácsképzés több szinten is végezhetö; az egyetemi szintü fordítóképzés (mesterképzés) 2009-ben indult el (Klaudy 2019). Jelenleg fordító és tolmács mesterszakon négy féléves egyetemi képzés az alábbi hét egyetemen müködik: Debreceni Egyetem BTK, ELTE BTK, Eszterházy Károly Katolikus Egyetem BMK, Miskolci Egyetem BTK, Pannon Egyetem MFTK, Pázmány Péter Katolikus Egyetem BTK, Szegedi Tudományegyetem BTK (www.felvi.hu, lásd még Vermes 2016, Szabó et al. 2018).

Klaudy Kinga (2015) írja a terminológia mint tantárgy megjelenéséről, hogy az ELTE-n folyó fordítóképzésben a terminológia sokáig nem volt jelen, de aztán 2003-ban önálló tárgyként vezették be az európai uniós szakfordítók szakirányú továbbképzésében, ezt követően 2009-ben a fordító és tolmács mesterszakon már szerepelt a tantervben gazdasági és jogi terminológia, 2012-től pedig általános terminológiai előadásokat indítottak, ezek oktatója 2019 tavaszáig Tamás Dóra Mária volt. A Pázmány Péter Katolikus Egyetem Bölcsészettudományi Karán a fordító mesterszakon már az indulástól, 2012-től megkezdődtek az általános terminológiai témájú előadások (oktatók: Fóris Ágota, ezt követően Novák Barnabás, Papp Eszter, majd Horváth Péter Iván). A fordító és tolmács mesterképzés Képzési és Kimeneti Követelményeiben (KKK) egyébként a szakdolgozat követelményei között szerepel, hogy külön fejezetben kell tárgyalni a feldolgozott téma terminológiáját, oly módon, hogy a forrásnyelvi és célnyelvi terminusokat kontextussal, definícióval és forrásmegjelöléssel kell ellátni:

A mesterképzés képesítési követelményeinek kidolgozásakor a terminológia bekerült az ismeretek számonkérésébe is, a fordítók és tolmácsok diplomamunkájában külön fejezetet kell szentelni a feldolgozott téma terminológiájának. Kezdettől fogva ügyeltünk arra, hogy ne párhuzamos szójegyzéket kérjünk, hanem forrásnyelvi és célnyelvi kontextussal ellátott terminusokat definícióval, lelöhely- és forrásmegjelöléssel. (Klaudy 2017: 10)

A témához kapcsolódó hasznos kézikönyv A modern fordító és tolmács címmel megjelent gyüjteményes kötet (Horváth 2015b) és egy oktatási segédanyag Bevezetés a jogi terminológiába a terminológus szemüvegén át címmel (Tamás 2019).

Ezen túl számos felsőoktatási intézmény kínál fordítói specializációt mint szakirányú továbbképzést - e specializációk keretében is gyakran szerepel a tantervben terminológia vagy terminográfia témájú kurzus. Ennek a típusú képzésnek van a legnagyobb hagyománya Magyarországon, mivel a tudományegyetemek bölcsészkarán és a szakegyetemeken is évtizedek óta vehetnek fel a hallgatók fordítói specializációt (korábban ágazati szakfordítóképzésnek, majd szakosító 
továbbképzésnek, később szakirányú továbbképzésnek nevezték). Az ELTE-n korábban európai uniós szakfordító- és konferenciatolmács-képzést folytattak, jelenleg az alábbi kettő (illetve három) féléves szakirányú továbbképzésekre lehet jelentkezni: társadalomtudományi és gazdasági szakfordító; gazdasági és jogi szakfordító és terminológus; európai uniós konferenciatolmács; bírósági és hatósági tolmács; szakfordító és audiovizuális fordító; gazdasági és jogi szakfordító és lektor; szakfordító és nyelvi mérnök. Ilyen fordítói szakirányú képzést folytat még többek között a BME GTK például a gazdasági, müszaki és európai uniós szakfordító; müszaki, gazdasági és társadalomtudományi szakfordító; müszaki, gazdasági és társadalomtudományi tolmács; nemzetközi három idegen nyelvü konferenciatolmács továbbképzéseken. A Károli Gáspár Református Egyetem BTK két féléves szakirányú továbbképzést folytat bölcsészettudományi, egyházi, jogi, gazdasági, müszaki, európai uniós és társadalomtudományi két idegen nyelvü szakfordítói és müfordítói (választható nyelvek: angol, francia, holland, japán, kínai, német nyelv) specializáción. A PPKE ÁJK-n angol jogi szakfordító és angol jogi szakfordító szakjogász, a PPKE BTK-n pedig irodalmi fordító/müfordító angol nyelvből nevü szakirányú továbbképzésekre lehet jelentkezni. (Az adatok a felvi.hu-ról származnak; ezek az egyes intézmények által 2021 szeptemberétől meghirdetett képzések, indításuk a jelentkezők számától függ.) A sort nem folytatom, a fordítói képzések minden egyes egyetemen nagyon népszerúek, és ezek keretében a fordítók számára fontos terminológiai ismeretek oktatása is beépül a tantervekbe. E képzések részletes bemutatását és összegző értékelését megtaláljuk a Magyarországi forditóképzö intézmények SWOT-elemzése címü tanulmányban (Szabó et al. 2018).

A fordítóképzések tapasztalatairól (pl. Dróth 2010, Élthes 2010), a terminológiának a fordítás oktatásában játszott szerepéről már évtizedek óta születnek publikációk (pl. Heltai 1988, 2010, Fischer 2015). Az egyik fontos, az oktatáshoz kapcsolódó kérdés a fordítások értékelése (Lesznyák és Balogh 2018), ezen belül a terminológia megfelelő ismerete és használata. Dróth Júlia kiemeli, hogy a fordítások értékelésénél fontos szempont az, hogy a fordítók megfelelően ismerik-e a terminológiát:

Kiemelt szerepet kap a reáliák, a terminológia megfelelő ismerete, felkutatása, szakszerü kezelése, valamint a számítógépes eszközök használata. Így például a terminológiának, intézményneveknek stb. illeszkednie kell a szakterület egyéb célnyelvi szövegeinek kifejezésmódjához, a formátumnak ki kell szolgálnia a felhasználó konkrét igényeit stb. (Dróth 2011: 8)

A fordítóképzésben részt vevő hallgatóknak általában nehézséget okoz a megfelelö terminusok megtalálása, a terminológia megfelelö kezelése. Fischer Márta $(2012,2014)$ számos konkrét példán illusztrálja ezeket a nehézségeket, és a hivatkozott tanulmányában általános módszertani ötleteket ad arra nézve, milyen módon érdemes a szemináriumokon feldolgozni a terminológia elméleti kérdéseit, és 
hogyan érdemes hozzáfogni a szövegek terminológiai szempontú feldolgozásához, valamint hogyan lehet növelni a hallgatók motivációját.

\subsection{A fordítói kompetenciák}

Az Európai Unió nagyszámú fordítót és tolmácsot alkalmaz intézményeiben. Az EU tagországainak különböző felsőoktatási intézményeiben sokáig különböző tematikájú és szintü fordító- és tolmácsképzés folyt, ezért szükségessé vált a fordítói kompetenciák meghatározása és összehangolása (lásd pl. Pym 2013). A fordítóképzés kimeneti kompetenciakövetelményeit meghatározó modellek közül a fordítással foglalkozó szakirodalomban a PACTE csoport $^{3}$ (lásd a fordítói kompetenciakutatásokról szóló összefoglaló tanulmánykötetet: Hurtado Albir 2017) és az EMT által alkotott modelleket emelik ki. Az Európai Unió Fordítási Főigazgatóságának EMT (European Masters in Translation) ${ }^{5}$ szakértői csoportja által 2009-ben kidolgozott és 2017-ben pontosított modell elsősorban a felsőoktatásban müködö fordítóképző intézmények számára nyújt útmutatást. Ehhez kapcsolódva Szabó és munkatársai a magyar fordítóképző intézményekröl végzett SWOT-analízisükben megállapítják, hogy a képzések mindegyikében jelen van a fordításelmélet, a tolmácsoláselmélet és a terminológia tárgyak oktatása (Szabó et al. 2018: 19). A kétféle kompetenciamodell az alábbi készségek elsajátítását tartja szükségesnek:

A PACTE csoport a következő részkészségek elsajátítását tartja elengedhetetlennek: a két nyelv ismerete, a nyelvektől független tudás, a fordítással kapcsolatos ismeretek, valamint az instrumentális, a stratégiai és a pszichofiziológiai kompetenciák. Az EMT-modell a tematikus, ${ }^{6}$ a nyelvi, az interkulturális, az információkeresési és a technológiai kompetenciákat különbözteti meg. (Szabó et al. 2018: 8)

Az egy évtized alatt lezajlott változások - mint a technológiai fejlődés, a gépi fordítás előtérbe kerülése, vagy a mesterséges intelligencia megjelenése a szolgáltatásokban - miatt 2017-ben az EMT a fordítói mesterképzésben oklevelet szerző hallgatóktól elvárt általános kompetenciákat és specifikus készségeket módosította; ebben a dokumentumban az alábbi kompetenciaterületeket sorolja fel: ${ }^{7}$ (1) nyelvi és kulturális kompetenciák (transzkulturális és szociolingvisztikai tudatosság és kommunikációs készség), (2) fordítási kompetenciák (stratégiai, módszertani és tematikai/szakterületi kompetencia), (3) technológiai kompetenciák (eszközök és alkalmazások), (4) személyes és személyek közötti kompetenciák (általános készségek, amelyekre gyakran „puha készségek”-ként hivatkoznak), (5) szolgáltatásnyújtási kompetenciák. Ez alapján az egyértelműen látszik, hogy a fordító- és tolmácsképzések nagyon széleskörü kompetenciafejlesztést tüztek ki célul, és hogy ma már elsősorban a nyelvipar számára (a teljes fordítási projektfolyamat számára) kívánnak szakembereket képezni. Ezek az elképzelések rendkívül széles spektrumú és egyúttal mély szakmai képzést követelnének meg, ahol sokféle kompetenciát kellene 
nagy mélységben elsajátíttatni a fordítókkal. Veresné Valentinyi a szakfordítói kompetenciákról végzett vizsgálatában arra a következtetésre jut, hogy „Időbeni, pénzügyi és személyi (oktatóhiány) korlátok miatt feltételezzük, hogy a honi szakfordító szakirányú továbbképzések egyike sem tudja felvállalni az összes kompetencia oktatását. Megoldás lehet olyan szakfordító szakirányú továbbképzések indítása, amelyek az egyes kompetenciacsoportokra specializálódnak" (Veresné Valentinyi 2020: https://mersz.hu/hivatkozas/nykiltlf_176\#nykiltlf_176).

Érdekes, hogy míg a terminológia mint tantárgy mindegyik fordítóképzésben jelen van, addig a fordítói kompetenciák között nem szerepel kiemelten, annak ellenére, hogy a nemzetközi szakirodalomban is régóta írnak a terminológiai kompetencia fejlesztésének fontosságáról a fordítóképzésben. Úgy látszik, hogy a kompetenciamodellekben a terminológiával kapcsolatos ismeretek a fordítástechnika és a fordítástechnológia területéhez, illetve a technológiai kompetenciák közé sorolódnak, kiemelten a fordítási környezetek, a CAT-eszközök és az IKT használatának részeként.

\subsection{A terminológiai kompetencia}

A nemzetközi szakirodalomban több szerző is rámutat arra, hogy mennyire fontos a fordítók terminológiai kompetenciájának fejlesztése, és hogy mi az, amire a fordítóknak szükségük van ebben a folyamatban (pl. Budin 2016). Montero Martínez és Faber (2009) szerint a fordítást végző hallgatóknak meg kell tanulniuk, hogyan végezzenek leíró terminológiai munkát megfelelő célszöveg elöállítása céljából, és hogy a terminológiai kompetencia fejlesztését a fordítási munkafolyamat során felmerülő igényekhez érdemes igazítani. A forrásszöveg elemzése és a célszöveg előállítása során a fordítónak sikeresen kell kezelnie a terminológiai problémákat, ezért stratégiákat kell kidolgoznia a következő folyamatok végrehajtására: a diskurzusban aktiválódó speciális fogalmak azonosítása és elsajátítása; az információs erőforrások értékelése, konzultációja és kidolgozása; a fogalmakon alapuló nyelvek közötti megfeleltetések felismerése; a megszerzett információk és ismeretek kezelése és újrafelhasználása a jövőbeni fordításokban (Montero Martínez és Faber 2009: 92). Montero Martínez és Faber ebben az idézett tanulmányban felvázolják egy fordítóknak szóló terminológiai oktatási program vázlatát. Ezt négy nagy egységre osztják: (1) bevezetés a terminológiába, (2) a terminológia elmélete és gyakorlata, (3) terminológia a fordításban és (4) terminográfiai dokumentáció a fordítási folyamatban. Az első három témára 40 tanórát terveztek, a negyedik témára, melyet teljes egészében projektmunkaként képzelnek el, további 40 tanórát, vagyis összesen 80 órás kurzust tartanak szükségesnek a terminológiai ismeretek fordítók számára történő átadására.

Az Iránytü az egyetemi forditóképzéshez. A kompetenciafejlesztés új fókuszai címü kötetet azzal a céllal hozta létre a fordítóképzésben oktató néhány kolléga, hogy a szakfordítóképzésekben fejlesztendő kompetenciákat összegyüjtsék, és irányt mutassanak a többi oktatónak (Kóbor és Csikai 2017). Az e kötetben meg- 
jelent tanulmányában Fischer is megállapítja a fordítói/fordítási kompetenciamodellekböl, hogy a terminológia legfeljebb a felsorolt kompetenciák egy-egy elemeként jelenik meg, és amellett foglal állást, hogy a terminológiai kompetenciát mint önálló kompetenciát kellene kezelni. A terminológiai kompetenciát négy elemből álló egységként írja le: ,a terminusok felismerése, a terminusok megfeleltetése a megnevezések és a fogalmak szintjén, a terminusok keresése/alkotása, a terminusok rögzítése (terminológiamenedzsment)" (Fischer 2017: 30-32). Sermann Eszter egy projektleírásban mutatja be a terminológiai kompetencia fejlesztésének módszerét és eredményeit a fordító- és tolmácsképzésben (Sermann 2019). Seidl-Péch Olívia, Kóbor Márta és Sermann Eszter (2020) A terminológiai kompetencia a forditóképzésben címmel megjelent tanulmányukban a terminológiai kompetencia két fö területét emelik ki: az egyik a terminusok kezelése és a célnyelvi megfelelök felkutatása, a másik a terminológiakezelő szoftverek használata. Az e tanulmányukban bemutatott intézményközi projekt egy fordítási feladat előkészítését szimulálta; a hallgatók terminológiai kompetenciáját fejlesztették oly módon, hogy egy olasz, francia vagy német forrásnyelvü párhuzamos szöveget kellett fordításra előkészíteniük. A forrásnyelvi szöveg alapján a hallgatók dolgozták ki a terminológiai adatbázis adatait, közösen végezték el a terminuskivonatolást, majd a terminusokat terminológiai adatbázisban rögzítették. Az elkészült terminológiai bejegyzések ön- és társas értékelésével került sor a minőség-ellenőrzésre. A szerzők egyik megállapítása, hogy a hallgatók számára a legfőbb nehézséget „annak megítélése jelentette, hogy mely lexikai egység tekinthető az adott kontextusban terminusnak, és melyik köznyelvi szónak", ezen kívül nehézségeik voltak a definíciók megadásával és a megbízható források felkutatásával - vagyis e területeken szükséges a képzésben az elméleti előkészítés.

\subsection{Hallgatói projektek: terminológiai adatbázisok bejegyzéseinek készítése}

A fordító- és terminológusképzésekben gyümölcsöző az együttmüködés olyan intézményekkel, amelyek fordítói munkát végeznek, és van folyamatosan fejlesztett terminológiai adatbázisuk. Számos nemzetközi intézménynek van terminológiai együttműködése különböző egyetemek fordító- és terminológusképzésével, általában két területen: hallgatói közremüködés a terminológiai adatbázis bejegyzéseinek bővítésében, valamint szakértői együttmüködés egyetemekkel és szakmai szervezetekkel. Többek között az Európai Unió fordítószolgálatai adnak lehetőséget ilyen együttmüködésre, valamint az ENSZ Szellemi Tulajdon Világszervezete (WIPO). A magyarországi fordítóintézmények közül az Országos Fordító és Fordításhitelesítő Irodának (OFFI Zrt., www.offi.hu) van gyakornoki programja, ennek keretében fordító és terminológus gyakornokokat is fogadtak. Ezenkívül más, privát tulajdonú fordítóirodák is rendszeresen fogadnak fordító és terminológus gyakornokokat, mint például a LEG Magyarország Zrt. (www.leg.eu), a T.É.K. Localizations Kft. (https://www.tekloc.net/hu/). 
Az Európai Parlament ${ }^{8} 2012$ óta ad lehetőséget olyan egyetemeknek, amelyeken terminológia tárgyat oktatnak, hogy hallgatóikkal bekapcsolódjanak a IATE terminológiai adatbázis adatokkal való feltöltésébe. ${ }^{9}$ A kidolgozott terminusok elvárható száma hallgatónként 5-10 db szokott lenni. Ezen túl a terminológia mesterszakos hallgatóknak ajánlanak egy olyan projektet, amely szakdolgozati témának alkalmas: 50-100 terminus szócikkének (bejegyzésének) kidolgozása a IATE sablonja alapján. A Parlament által meghirdetett programhoz csatlakozott az ELTE BTK posztgraduális gazdasági és jogi szakfordító és terminológus továbbképzés keretében Tamás Dóra Mária a „Fordítási és terminológiai projektmunka” nevü szemináriumi csoportjával a 2016/2017. és a 2018/2019. tanév tavaszi félévében. ${ }^{10}$

Az Európai Bizottság Fordítási Főigazgatóságának (DGT) Magyar Nyelvi Osztálya 2019/2020. őszi félévében indított első alkalommal magyar egyetemekkel közös terminológiai projektet, amelyet folytatni szándékoznak a jövőben. Ezekben a projektekben a hallgatók szakmailag már ellenőrzött és jóváhagyott szövegeket dolgoznak fel, ezek alapján végeznek terminuskivonatolást. Az ellenőrzés több fázisban zajlik: a kurzus keretében önellenőrzés, társas ellenőrzés, és az oktató is ellenörzi a munkájukat; ebben a fázisban nem a terminusok ekvivalenciáját ellenőrzik, hanem a munkamódszer, a kontextus és a definíció minőségét. Miután az elkészült anyagokat átadják a DGT munkatársainak, azt ők is ellenőrzik, majd az átadott anyagokat gyakornokok viszik fel az adatbázisba, és ezek után az európai uniós terminológusok validálják ezeket. ${ }^{11}$ A Magyar Nyelvi Osztály többször is jelezte a fordítóképzéssel és terminológiaoktatással foglalkozó intézményeknek, hogy nyitott egy ilyen együttmüködésre. Ehhez a programhoz csatlakozott Kóbor Márta (DGT), Seidl-Péch Olívia (BME) és Sermann Eszter (SZTE) csoportja az e célból alakított intézményközi projekt keretében 2019-ben, majd 2020-ban (SeidlPéch et al. 2020).

Egy másik, hasonló együttműködés volt az ENSZ Szellemi Tulajdon Világszervezete (World Intellectual Property Organization, WIPO) szabadalmi fordítási osztályával (Translation Cooperation Treaty [PCT] Translation Division) közösen megvalósított egyetemi hallgatói terminológiai projekt, melynek során a hallgatók valós feladatmegbízás keretében járultak hozzá a WIPO Pearl szabadalmi terminológiai adatbázis bejegyzéseinek bővítéséhez. Először a 2018/2019. tanévben, az ELTE BTK gazdasági és jogi szakfordító és terminológus posztgraduális képzése keretében, „Fordítási és terminológiai projektmunka” szemináriumon vettek részt a hallgatók terminológiai bejegyzések kidolgozásában, majd a 2019/2020. és a 2020/2021. tanév tavaszi félévében a BME müszaki, gazdasági és társadalomtudományi szakfordítóképzésében a „Fordítástechnológia és terminológiamenedzsment" szeminárium keretében, mindhárom szemináriumot Tamás Dóra Mária vezette. Tamás Dóra (2020) egy tanulmányában pontosan ismerteti a fogadó intézmény (jelen projektben a Szellemi Tulajdon Világszervezet) feltételeit a munkába való bekapcsolódáshoz, a tantárgy tematikáját és a hallgatók szakmai hátterét, továbbá lépésről lépésre részletesen mutatja be a projekt lépéseit és tanul- 
ságait. A szerző kiemeli, hogy ebben a projektben a terminusok felismerésén és a terminusok rögzítésén volt a hangsúly, de a fogalmi háló építésével megjelentek ontológiai ismeretek is, valamint fontos szerepet kapott az információkeresés és a dokumentáció. A hallgatók feladata fejenként $5 \mathrm{db}$ terminus kidolgozása volt; mivel az adatbázisban magyar nyelvü adatok nem szerepelnek, angol nyelvü terminusokat dolgoztak fel a hallgatók. Tamás így mutatja be a projekt fázisait:

A WIPO-PCT munkatársaitól kapott információk és a WIPO-PCT útmutatói alapján a projekt tervezett menetrendje hagyományosan a következő munkafázisokból áll:

- a szervezet, a terminológiai adatbázis és a feladatok bemutatása prezentáció formájában;

- a domén kiválasztása az intézmény részéről és jóváhagyása a WIPO munkatársai részéröl;

- szövegkorpusz létrehozása, majd abból a terminusok kivonatolása;

- a terminuslista megküldése jóváhagyásra a WIPO munkatársainak;

- a jóváhagyott terminuslista alapján az ekvivalensek és a kontextus keresése és rögzítése bibliográfiával együtt a megadott módon;

- a kidolgozott adatok rögzítése fordítástámogató szoftverrel a WIPO sablonfájljában;

- végül a fogalmi háló kidolgozása, a terminológiai adatbáziskezelö-szoftverrel elóállított fájlok és a fogalmi háló leadása;

- kiértékelés;

- a bejegyzések a WIPO munkatársainak feldolgozásával, kiegészítésével és validálásával megjelenthetnek a WIPO Pearl adatbázisban. (Tamás 2020: 28-29)

A hivatalos angol nyelvü tematikus útmutatókon felül Tamás egy magyar nyelvü, lineáris, a munkamenetet specifikusan követő leírást is készített a hallgatók számára.

A források alapján megállapítható, hogy a legtöbb fordítóképzésben a képzés első szemeszterében a hallgatók terminológiaelmélet előadást hallgatnak, a második szemeszterben pedig terminológia (vagy terminológiamenedzsment vagy fordítástechnológia nevü) szemináriumon vesznek részt; így az előadáson az alapfogalmak megismerésével készülnek fel, a szemináriumon pedig már képesek a terminológiai projektmunkára. (Mind az előadások, mind a szemináriumok óraszáma egy szemeszterben általában 24 óra, tehát 2 tanóra/hét, vagyis ebben a rendszerben a fordítóképzések összesen 48 tanórát szánnak a terminológiai kompetencia fejlesztésére.) 


\section{4. Összefoglalás}

A tanulmányban a terminológia oktatását és kutatását mutattam be a fordítástudományi doktori képzésben és a fordítóképzésben. Bemutattam, hogy a fordítóiparban nagy szükség van terminológiai munkára és terminológusokra, és arra is, hogy a fordítók képesek legyenek a terminológia és a terminológiamenedzsment-eszközök kezelésére, ezért a fordítóképzésben is elengedhetetlen a terminológia oktatása. A magyarországi fordítóképzésekben a terminológia mint tantárgy jelen van, a kompetenciamodellekben azonban a terminológiával kapcsolatos ismeretek a fordítástechnika és a fordítástechnológia területéhez, illetve a technológiai kompetenciák közé sorolódnak, kiemelten a fordítási környezetek, a CAT-eszközök és az IKT használatának részeként. Több nemzetközi intézménynek van terminológiai együttmüködése egyetemek fordító- és terminológusképzésével, általában két területen: hallgatói közremüködés a terminológiai adatbázis bejegyzéseinek bővítéséhez, valamint szakértői együttmüködés egyetemekkel és szakmai szervezetekkel.

\section{Támogatás}

A tanulmány elkészítését a KRE BTK „Interkulturális transzferjelenségek és a (mű)fordítás című projekt”; „Fordítás és terminológia kapcsolata: a terminológia szerepe az interkulturális transzfer folyamatában" címü kutatási pályázata támogatta.

\section{Irodalom}

Ábrányi H. 2015. A fordítási környezetek hatása a forditás minöségére. PhD-értekezés. Budapest: ELTE BTK, kézirat. (témavezető: Kis Balázs)

Ábrányi H. 2015. Fordítási környezetek. In: Horváth I. (szerk.) A modern forditó és tolmács. Budapest: ELTE Eötvös Kiadó. 147-160.

B. Papp E., Fóris Á., Bölcskei A. 2014. Terminográfiai módszerek és eszközök a terminológusképzésben. In: Bocz Zs. (szerk.) Porta Lingua 2014. Szaknyelvi regiszterek és használati színterek. Budapest: Szaknyelvoktatók és -Kutatók Országos Egyesülete. 205-212.

Bereczné Szép B. 2014. A szakfordítás szerepe a magyar gazdasági jogi szakszókincs kialakulásában. PhD-értekezés. Budapest: ELTE BTK, kézirat. (témavezető: Nyomárkay István)

Budin, G. 2016. Terminology as a key competence for translators. Interpreting and Translation Studies 20. évf. 4. szám. 253-282.

Dróth J. 2010. A két féléves Társadalomtudományi és gazdasági szakfordító szakirányú továbbképzés első tapasztalatai. In: Dróth J. (szerk.) Szaknyelv és szakforditás. Tanulmányok a szakforditás és a forditóképzés aktuális témáiról 2009-2010. Gödöllő: Szent István Egyetem TTI. 86-91. 
Dróth J. 2011. A fordítások értékelése a szakfordítóképzésben és a fordítói munka világában. Fordítástudomány XIII. évf. 2. szám. 5-36.

Élthes Á. 2010. A szakfordítás tantárgyi programjának harmonizációjáról a BME GTK Idegennyelvi Központ Tolmács- és Fordítóképző Központjában. Szakfordító és tolmács szakirányú továbbképzési szak. In: Dróth J. (szerk.) Szaknyelv és szakforditás, Tanulmányok a szakforditás és a forditóképzés aktuális témáiról 2009-2010. Gödöllö: Szent István Egyetem TTI. 67-74.

Eszenyi R. 2015. Hány lábon álljon a fordító? A modern fordító profilja. In: Horváth I. (szerk.) A modern forditó és tolmács. Budapest: ELTE Eötvös Kiadó. 11-20.

Faludi A. 2020. A terminológiai munka helye és szerepe a dokumentációkészités és -forditás komplex folyamatában. PhD-értekezés. Budapest: ELTE BTK, kézirat. (témavezetö: Fóris Ágota)

Fischer M. 2011. A forditó mint terminológus, különös tekintettel az európai uniós kontextusra. PhD-értekezés. Budapest: ELTE BTK, kézirat. (témavezető: Muráth Judit)

Fischer M. 2012. Elméleti és módszertani adalék a terminológia oktatásához I. Terminológiaelméleti alapkérdések a fordításban. Forditástudomány XVI. évf. 2. szám. 5-30.

Fischer M. 2014. Elméleti és módszertani adalék a terminológia oktatásához II. Általános módszertani ötletek. Fordítástudomány XVI. évf. 2. szám. 55-70.

Fischer M. 2015. Terminológiaoktatás a szakfordítóképzésben: mit, mennyit, hogyan? In: Fata I., Veresné Valentinyi K. (szerk.) Szaknyelv és szakforditás. Tanulmányok a szakforditás és a forditóképzés aktuális témáiról. Gödöllö: Szent István Egyetem TTI. 41-55.

Fischer M. 2017. Kompetenciafejlesztés a szakfordítóképzésben - örök dilemmák, régi-új módszerek és a terminológiai kompetencia. In: Kóbor M., Csikai Zs. (szerk.) Iránytü az egyetemi forditóképzéshez. A kompetenciafejlesztés új fókuszai. Pécs: Kontraszt. 30-32.

Fóris Á. 2012. Terminológusok képzése - a terminológia mesterképzés elindulása. $M a$ gyar Tudomány 173. évf. 8. szám. 969-976. http://www.matud.iif.hu/2012/08/11.htm

Fóris Á. 2013. A terminológia-oktatás mint a magyar nyelv, kultúra és identitás támogatása. Magyar Terminológia 6. évf. 2. szám. 185-195.

Fóris Á. 2020. Forditás és terminológia. Elmélet és gyakorlat. Budapest: Károli Gáspár Református Egyetem - L'Harmattan Kiadó.

Földes A. 2015. Projektmenedzsment. In: Horváth I. (szerk.) A modern forditó és tolmács. Budapest: ELTE Eötvös Kiadó. 67-74.

Heltai P. 1988. Contrastive Analysis of Terminological Systems and Bilingual Technical Dictionary. International Journal of Lexicography 1. évf. 1. szám. 32-40.

Heltai P. 2010. Terms in English and Hungarian Specialized Texts. In: Dróth J. (szerk.) Szaknyelv és szakforditás, Tanulmányok a szakforditás és a forditóképzés aktuális témáiról 2009-2010. Gödöllő: Szent István Egyetem TTI. 8-27.

Horváth I. 2015a. Információs és kommunikációs technológiák a tolmácsolásban és a gépi tolmácsolás. In: Horváth I. (szerk.) A modern fordító és tolmács. Budapest: ELTE Eötvös Kiadó. 161-169.

Horváth I. (szerk.) 2015b. A modern forditó és tolmács. Budapest: ELTE Eötvös Kiadó. Hurtado Albir, A. (ed.) 2017. Researching Translation Competence by PACTE Group. Amsterdam-Philadelphia: John Benjamins. 
Klaudy K. 2008. Tizenöt tézis a fordítástudományról. In: Sárdi Cs. (szerk.) Kommunikáció az információs technológia korszakában. A XVII. MANYE Kongresszus elöadásai. Siófok. 2007. április 19-21. (A MANYE Kongresszusok Előadásai 4.) Pécs-Siófok: MANYE - Kodolányi János Föiskola. 40-51.

Klaudy K. 2013. A Fordítástudományi Doktori Program tíz éve. In: Klaudy Kinga (szerk.) Forditás és tolmácsolás a harmadik évezred elején: 40 éves az ELTE Forditó- és Tolmácsképzö Tanszéke. Budapest: ELTE Eötvös Kiadó. 19-31.

Klaudy K. 2014. Tízéves a Fordítástudományi Doktori Program (2003-2013). In: Ladányi M., Vladár Zs., Hrenek É. (szerk.) Nyelv, társadalom, kultúra: interkulturális és multikulturális perspektivák I-II.: a XXIII. Magyar Alkalmazott Nyelvészeti Kongresszus (ELTE BTK Budapest, 2013. március 26-28.) elöadásaiból készült tanulmánykötet. (A MANYE Kongresszusok Előadásai 10.) Budapest: MANYE - Tinta Könyvkiadó. $172-178$.

Klaudy K. 2015. A fordítástudomány interdiszciplináris kapcsolatairól: terminológia. In: Benő A., Fazakas E., Zsemlyei B. (szerk.) Többnyelvüség és kommunikáció KeletKözép-Európában. XXIV. Magyar Alkalmazott Nyelvészeti Kongresszus: Kolozsvár, 2014. április 24-26. (A MANYE Kongresszusok Előadásai 11.) Kolozsvár: Erdélyi Múzeum Egyesület. 175-181.

Klaudy K. 2017. Egyirányú interdiszciplinaritás: a fordítástudomány kapcsolata a terminológiával és a pragmatikával. Fordítástudomány XIX. évf. 1. szám. 5-21.

Klaudy K. 2019. A társadalmi megrendelés szerepe a fordítástudomány fejlődésében: az OFFI és a fordítóképzés kapcsolatának kezdetei. In: Szoták Sz. (szerk.) Az állami forditószolgálat 150 éve. Budapest: OFFI. 47-61.

Kóbor M., Csikai Zs. (szerk.) 2017. Iránytü az egyetemi forditóképzéshez. A kompetenciafejlesztés új fókuszai. Pécs: Kontraszt.

Lengyel I. 2014. A forditási hiba fogalma funkcionális megközelitésben. PhD-értekezés. Budapest: ELTE BTK, kézirat. (témavezető: Prószéky Gábor)

Lengyel I. 2015. Fordításértékelés ipari alapokon: a professzionális fordításértékelés módszerei. In: Horváth I. (szerk.) A modern forditó és tolmács. Budapest: ELTE Eötvös Kiadó. 107-120.

Lesznyák M., Balogh D. 2018. Jogi szakfordítások pedagógiai és kutatási célú értékelése: egy értékelési rendszer kidolgozásának dilemmái és tapasztalatai. In: Hilóczki Á., Fischer M., Szabó Cs. (szerk.) Fókuszban a forditás értékelése: Tanulmányok a BME INYK Tolmács- és Fordítóképzö Központ 2017. szeptember 29-30-án megrendezett Öszi Konferenciájának elöadásaiból. Budapest: BME. 125-146. https://www.offi.hu/ sites/default/files/media/files/fokuszban a forditas.pdf

Mohácsi-Gorove A. 2015. A minöség fogalma a fordítástudományban és a lektorálás mint minöségbiztositási garancia. PhD-értekezés. Budapest: ELTE BTK, kézirat. (témavezető: Kis Balázs)

Montero Martínez, S. - Faber, P. 2009. Terminological competence in translation. Terminology 15. évf. 1. szám. 88-104.

Pym, A. 2013. Translation skill-sets in a machine-translation age. Meta Vol. 58. No. 3. 487-503. http://id.erudit.org/iderudit/1025047ar

Robin E. 2015. A fordító mint lektor. In: Horváth I. (szerk.) A modern fordító és tolmács. Budapest: ELTE Eötvös Kiadó. 35-46. 
Seidl-Péch O., Kóbor M., Sermann E. 2020. A terminológiai kompetencia a fordítóképzésben. Egy intézményközi projekt tanulságai. In: Fóris Á., Bölcskei A. (főszerk.) Nyelv, kultúra, identitás. Alkalmazott nyelvészeti kutatások a 21. századi információs térben. I. Terminológia, lexikográfia, forditás. (A MANYE Kongresszusok Előadásai 12/1.) Budapest: Akadémiai Kiadó. https://mersz.hu/hivatkozas/nykiltlf_186 https://mersz.hu/hivatkozas/nykiltlf 193, utolsó megtekintés: 2020. 07. 06.

Sermann E. 2014. A terminológiai szabványositás és a terminológiai harmonizáció fordítási vonatkozásai. PhD-értekezés. Budapest: ELTE BTK, kézirat. (témavezető: Fóris Ágota)

Sermann E. 2019. Lo sviluppo della competenza terminologica nell'ambito della formazione di traduttori ed interpreti. In: Gazsi R. D. (szerk.) LINGUA CORVINUS NYELVI NAPOK: Tanulmánykötet. Budapest: Budapesti Corvinus Egyetem. 160-169.

Snopek M. 2015. Lokalizáció. In: Horváth I. (szerk.) A modern forditó és tolmács. Budapest: ELTE Eötvös Kiadó. 97-106.

Szabó Cs., Seidl-Péch O., Ugrin Zs. 2018. Magyarországi fordítóképző intézmények SWOT-elemzése. In: Hilóczki Á., Fischer M., Szabó Cs. (szerk.) Fókuszban a fordítás értékelése: Tanulmányok a BME INYK Tolmács- és Forditóképzö Központ 2017. szeptember 29-30-án megrendezett Öszi Konferenciájának elöadásaiból. Budapest: BME. 5-54. https://www.offi.hu/sites/default/files/media/files/fokuszban_a forditas. pdf, utolsó megtekintés: 2020. 09. 26.

Szondy M. 2015. A fordító mint fordításszolgáltató. In: Horváth I. (szerk.) A modern fordító és tolmács. Budapest: ELTE Eötvös Kiadó. 21-34.

Tamás D. M. 2011. A gazdasági szakszövegek forditásának terminológiai kérdéseiröl az olasz-magyar nyelvpár esetében. PhD-értekezés. Budapest: ELTE BTK, kézirat. (témavezető: Fóris Ágota)

Tamás D. M. 2015. A fordító mint terminológus. In: Horváth I. (szerk.) A modern fordító és tolmács. Budapest: ELTE Eötvös Kiadó. 47-66.

Tamás D. M. 2019. Bevezetés a jogi terminológiába a terminológus szemüvegén át. Budapest: ELTE Eötvös Kiadó. (2. átdolgozott kiadás), https://www.offi.hu/sites/default/ files/media/files/bevezetes_a_jogi_terminologiaba.pdf (Letöltés: 2020. július 6.)

Tamás D. M. 2020. Együttmüködés a Szellemi Tulajdonjog Világszervezetével: a Budapesti Műszaki és Gazdaságtudományi Egyetemen végzett szabadalmi terminológiai egyetemi hallgatói projekt tapasztalatairól. Magyar Jogi Nyelv IV. évf. 2. szám. 26-41.

Varga Á. 2012. A gépi forditás minősége és javitási lehetőségei. PhD-értekezés. Budapest: ELTE BTK, kézirat. (témavezető: Prószéky Gábor)

Varga Á. 2015. Gépi fordítás. In: Horváth I. (szerk.) A modern fordító és tolmács. Budapest: ELTE Eötvös Kiadó. 135-146.

Varga K. 2015. Fordítások technikai előkészítése és utómunkája. In: Horváth I. (szerk.) A modern fordító és tolmács. Budapest: ELTE Eötvös Kiadó. 83-96.

Veresné Valentinyi K. 2020. Az EMT-kompetenciamodell és a képesítőfordítások lektori javításainak, megjegyzéseinek és kérdéseinek tanulságai a szakfordítói kompetenciák fejlesztéséhez. In: Fóris Á. - Bölcskei A. (főszerk.) Nyelv, kultúra, identitás. Alkalmazott nyelvészeti kutatások a 21. századi információs térben. I. Terminológia, lexikográfia, forditás. (A MANYE Kongresszusok Előadásai 12/1.) Budapest: Aka- 
démiai Kiadó. https://mersz.hu/hivatkozas/nykiltlf_168, utolsó megtekintés: 2021. 04. 20.

Vermes A. 2016. Fordítóképzés Magyarországon és az Amerikai Egyesült Államokban. In: Vermes A. (szerk.) A fordítás arcai. Ünnepi kötet A fordítás arcai cimü konferenciasorozat 10. évfordulója alkalmából. Eger: Líceum Kiadó. 181-217.

Wagner V. 2015. Vendormenedzsment. In: Horváth I. (szerk.) A modern forditó és tolmács. Budapest: ELTE Eötvös Kiadó. 75-82.

Zabóné Varga I. 2015. Müszaki szövegek forditásának terminológiai problémái németmagyar nyelvpárban jármüipari szövegek alapján. PhD-értekezés. Budapest: ELTE BTK, kézirat. (témavezető: Fóris Ágota)

\section{Források}

A magyar terminológiastratégia és az európai uniós terminológia kapcsolódási pontjai: kerekasztal-beszélgetés. Translating Europe Workshop, 2020. szeptember 25., vezette: Berencsi Katalin (DGT).

Cooperation with Universities on Terminology Projects, https://termcoord.eu/cooperationwith-universities-on-terminology-projects/, utolsó megtekintés: 2020. 09. 25.

ELTE BTK Fordítástudományi Doktori Program, http://www.languages.elte.hu

EMT Competence Framework - 2017, https://ec.europa.eu/info/sites/info/files/emt_competence_fwk_2017_en_web.pdf, utolsó megtekintés: 2020. 08. 14.

EMT Expert Group: Competences for professional translators, experts in multilingual and multimedia communication, 2009, https://ec.europa.eu/info/sites/info/files/emt_competences_translators_en.pdf, utolsó megtekintés: 2020. 08. 14 .

Európai Parlament $=$ European Parlament, https://www.europarl.europa.eu/at-your-service/en/work-with-us/traineeships, utolsó megtekintés: 2020. 09. 25.

https://www.felvi.hu, utolsó megtekintés: 2020. 12. 28.

IATE - hallgatói projekt vezetése, http://termcoord.eu/universities-projects/eotvos-loranduniversity-budapest-for-iate/ (tanév: 2016/2017. és 2018/2019. tanév (a tantárgy megnevezése: Fordítási és terminológiai projektmunka), utolsó megtekintés: 2021. 04. 20.

LEG Magyarország Zrt., www.leg.eu, utolsó megtekintés: 2020. 09. 25.

Országos Fordító és Fordításhitelesítő Iroda, www.offi.hu, utolsó megtekintés: 2021. 04.20. T.É.K. Localizations Kft., https://www.tekloc.net/hu/, utolsó megtekintés: 2020. 09. 25.

WIPO Pearl terminológiai adatbázis, https:/www.wipo.int/reference/en/wipopearl/, utolsó megtekintés: 2021. 04. 20.

\section{Jegyzetek}

1 Az ELTE BTK Fordítástudományi Doktori Programról szóló információk letölthetők az ELTE BTK Nyelvi Közvetítés Intézete Fordító- és Tolmácsképző Tanszékének honlapjáról: http://www.languages.elte.hu

2 Természetesen más doktori programokban is születtek a terminológia és/vagy a fordítás témájához sorolható tudományos értekezések, de a fordítási és terminológiai tudományos kutatásoknak elsősorban ez a doktori képzés adott otthont. 
3 A PACTE Group az Universitat Autònoma de Barcelona keretében működő kutatócsoport (PACTE - Procés d'Adquisició de la Competència Traductora i Avaluació). 1997 óta foglalkoznak a fordítói kompetenciák meghatározásával, fejlesztésével és a fordítás oktatási kérdéseivel.

${ }^{4}$ EMT Expert Group: Competences for professional translators, experts in multilingual and multimedia communication, 2009, https:/ec.europa.eu/info/sites/info/files/emt competences_translators_en.pdf(Letöltés: 2020. augusztus 14.)

${ }^{5}$ EMT (European Masters in Translation), tagja Magyarországról az ELTE FTT.

${ }^{6}$ Angolul thematic competence, a magyar nyelvü szakirodalomban tematikus/tematikai kompetencia - tulajdonképpen szakterületi kompetencia.

${ }^{7}$ EMT Competence Framework - 2017, https://ec.europa.eu/info/sites/info/files/emt competence_fwk_2017_en_web.pdf

${ }^{8}$ European Parlament, https://www.europarl.europa.eu/at-your-service/en/work-with-us/ traineeships

${ }^{9}$ Cooperation with Universities on Terminology Projects, https://termcoord.eu/cooperation-with-universities-on-terminology-projects/

${ }^{10}$ IATE - hallgatói projekt vezetése, http://termcoord.eu/universities-projects/eotvos-lorand-university-budapest-for-iate/ (2016/2017. és 2018/2019. tanév (a tantárgy megnevezése: Fordítási és terminológiai projektmunka).

${ }^{11}$ A magyar terminológiastratégia és az európai uniós terminológia kapcsolódási pontjai: kerekasztal-beszélgetés. Translating Europe Workshop, 2020. szeptember 25., vezette: Berencsi Katalin (DGT). 